

\title{
Synthesis and Structural Characterization of Four Novel Bisoxime-Type Compounds Based on 2,2'-(Ethylenedioxy)bisbenzaldehyde
}

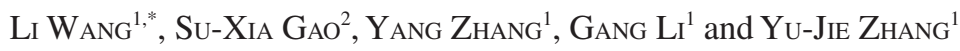

${ }^{1}$ School of Chemical and Biological Engineering, Lanzhou Jiaotong University, Lanzhou 730070, P.R. China

${ }^{2}$ School of Environmental and Municipal Engineering, Lanzhou Jiaotong University, Lanzhou 730070, P.R. China

*Corresponding author: E-mail: wangli_78@126.com

\begin{abstract}
A series of bisoxime compounds have been synthesized by the reaction of 2,2'-(ethylenedioxy)bisbenzaldehyde with hydroxylamine hydrochloride, methoxyamine hydrochloride, ethyoxylamine hydrochloride or 3-aminoacetophenone oxime in hot ethanol medium, respectively and characterized by elemental analyses, IR, UV-visible spectra and ${ }^{1} \mathrm{H}$ NMR spectroscopy.
\end{abstract}

Keywords: 2,2'-(Ethylenedioxy)bisbenzaldehyde, Bisoximes-type ligand, Synthesis, Characterization.

\section{INTRODUCTION}

Bisoxime-type compounds are a kind of multidentate chelating ligands and easily obtained by the reaction of bisamine and aldehyde or alkone, which can coordinated to transition metal ions to afford stable metal complexes ${ }^{1}$. However the oxime-type compounds play an important role in the development of coordination chemistry related to catalysis and enzymatic reactions, magnetism and molecular $\operatorname{architectures}^{2-5}$. In recent years, the research of the metalorganic complexes with these bisoxime-type ligands and transition metal ions have made great progress ${ }^{6-8}$. In order to investigating the structural properties of the bisoxime-type compounds more deeply, we have recently studied a series of bisxiome compounds from 2,2'-(ethylenedioxy)bis-benzaldehyde with hydroxylamine hydrochloride, methoxyamine hydrochloride, ethoxyamine hydrochloride or 3-aminoacetophenone oxime, respectively and the characterizations have also been studied.

\section{EXPERIMENTAL}

Salicylaldehyde ( $\geq 98 \%$ ), 1,2-dibromoethane, hydroxylamine hydrochloride, methoxyamine hydrochloride, ethyoxyamine hydrochloride and 3-aminoacetophenone were purchased from Alfa Aesar and used without further purification. The other reagents and solvents were analytical grade reagents from Tianjin Chemical Reagent Factory. The methods are the same as literature early .

General procedure: Synthetic route to bisoxime compounds $\mathrm{H}_{2} \mathrm{~L}^{1}, \mathrm{~L}^{2}, \mathrm{~L}^{3}$ and $\mathrm{H}_{2} \mathrm{~L}^{4}$ are shown in Fig. 1 .

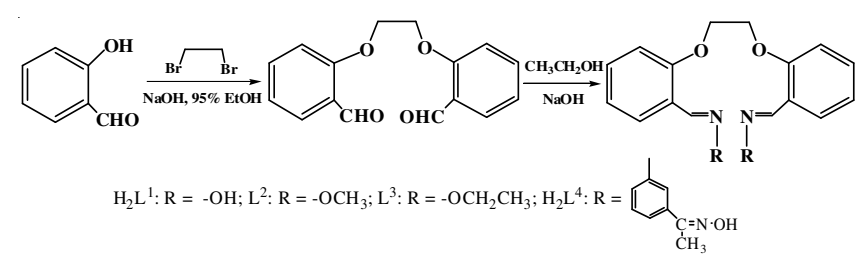

Fig. 1. Synthetic route to bisoximes-type compounds $\mathrm{H}_{2} \mathrm{~L}^{1}, \mathrm{~L}^{2}, \mathrm{~L}^{3}$ and $\mathrm{H}_{2} \mathrm{~L}^{4}$

2,2'-(1,2-Ethylenedioxy)bisbenzaldehyde was synthesized by refluxing of salicyaldehyde, sodium hydroxide and 1,2dibromoethane in ethanol-water mixture under nitrogen for $72 \mathrm{~h}^{9} .{ }^{1} \mathrm{H}$ NMR (400 MHz, DMSO- $\left.d_{6}, \delta / \mathrm{ppm}\right), 4.50$ (s, $4 \mathrm{H}$, $\left.\mathrm{CH}_{2} \mathrm{O}\right), 6.96(\mathrm{t}, 2 \mathrm{H}, J=7.7 \mathrm{~Hz}, \mathrm{ArH}), 7.15(\mathrm{~d}, J=7.7 \mathrm{~Hz}, 2 \mathrm{H}$, $\mathrm{ArH}), 7.36(\mathrm{t}, J=7.7 \mathrm{~Hz}, 2 \mathrm{H}, \mathrm{ArH}), 7.76(\mathrm{~d}, J=7.7 \mathrm{~Hz}, 2 \mathrm{H}$, $\mathrm{ArH}), 10.08$ (s, 2H, CH=O).

Preparation of 2,2'-(ethylenedioxy)bisbenzaldehyde dioxime $\left(\mathbf{H}_{2} \mathbf{L}^{1}\right)$ : To a hot ethanolic solution $(15 \mathrm{~mL})$ of 2,2'(ethylenedioxy)bisbenzaldehyde (270.3 mg, $1 \mathrm{mmol}$ ) was added an ethanolic solution $(15 \mathrm{~mL})$ of hydroxylamine hydrochloride ( $278 \mathrm{mg}, 4 \mathrm{mmol}$ ). After the solution had been stirred at $55^{\circ} \mathrm{C}$ for $1 \mathrm{~h}$, sodium hydroxide $(400 \mathrm{mg}, 10 \mathrm{mmol}$ ) was added slowly with shaking. The mixture was then refluxed for $15 \mathrm{~min}$, cooled to room temperature and poured into a solution of concentrated hydrochloric acid $(60 \mathrm{~mL})$ and water $(250 \mathrm{~mL})$. The formed precipitate was separated by filtration and washed three times successively with ethanol and ethanol/hexane (1:4), respectively. The product was dried under reduced pressure to obtain white powder $\mathrm{H}_{2} \mathrm{~L}^{1}$. Yield $82.5 \%$. m.p. $445-446 \mathrm{~K}$.

Preparation of N,N'-bismethoxy-2,2'-(ethylenedioxy)bisbenzaldehyde dioxime $\left(\mathbf{L}^{2}\right)$ : To a hot ethanolic solution 
$(15 \mathrm{~mL})$ of 2,2'-(ethylenedioxy)bisbenzaldehyde (270.8 mg, $1 \mathrm{mmol})$ was added an ethanolic solution $(15 \mathrm{~mL})$ of methoxyamine hydrochloride ( $334.3 \mathrm{mg}, 4 \mathrm{mmol})$. After the solution had been stirred at $55^{\circ} \mathrm{C}$ for $1 \mathrm{~h}$, sodium hydroxide $(400 \mathrm{mg}$, $10 \mathrm{mmol}$ ) was added slowly with constant shaking. The mixture was then refluxed for $25 \mathrm{~min}$, cooled to room temperature and poured into a solution of concentrated hydrochloric acid $(60 \mathrm{~mL})$ and water $(300 \mathrm{~mL})$. The formed precipitate was separated by filtration and washed three times successively with ethanol and ethanol/hexane (1:4), respectively. The product was dried under reduced pressure to obtain white powder $\mathrm{L}^{2}$. Yield 79.1 \%. m.p. 369-370 K.

Preparation of N,N'-bisethoxy-2,2'-(ethylenedioxy)bisbenzaldehyde dioxime $\left(\mathbf{L}^{\mathbf{3}}\right)$ : To a hot ethanolic solution (15 $\mathrm{mL}$ ) of 2,2'-(ethylenedioxy)bisbenzaldehyde $(270.3 \mathrm{mg}$, $1 \mathrm{mmol})$ was first added an ethanolic solution $(10 \mathrm{~mL})$ of ethoxyamine hydrochloride $(390.2 \mathrm{mg}, 4 \mathrm{mmol})$, then $\mathrm{NaOH}$ (400 mg, $10 \mathrm{mmol}$ ). After the mixture had been stirred under reflux for $4 \mathrm{~h}, 10 \mathrm{~mL}$ distilled water was added. The solution was filtered and concentrated to about $15 \mathrm{~mL}$ over night at $271 \mathrm{~K}$. The resulting pale-yellow solid product was filtered and washed successively with distilled water and ethanol/ hexane (1:4). The isolated compound was dried under vaccum to yield $242.7 \mathrm{mg}$ of the white powder $\mathrm{L}^{3}$. Yield $68.1 \%$. m.p. 337-338 K.

Preparation of N,N'-phenyl-3-acetyl oxime -2,2'-(ethylenedioxy)bisbenzaldehyde $\left(\mathbf{H}_{2} \mathbf{L}^{4}\right)$ : 3-Aminoacetophenone oxime was synthesized analogously to the method reported in the previous literature ${ }^{10}$. To a hot ethanolic solution $(7 \mathrm{~mL})$ of 3-aminoacetophenone $(818.2 \mathrm{mg}, 6 \mathrm{mmol})$ was added a mixed ethanolic solution $(15 \mathrm{~mL})$ of hydroxylamine hydrochloride (423.5 mg, $6 \mathrm{mmol}$ ) and sodium acetate trihydrate $(480.4 \mathrm{mg}$, $10 \mathrm{mmol}$ ), the colour of the mixing solution turned to paleyellow. The mixture was stirred at $55^{\circ} \mathrm{C}$ for $12 \mathrm{~h}$. After cooling to room temperature, the mixture was filtered, washed successively with ethanol and $n$-hexane, respectively. The product was dried under reduced pressure to obtained brown needlelike solid. Yield, $68.2 \%$. m.p. 408-409 K. Anal. Calcd. for $\mathrm{C}_{8} \mathrm{H}_{10} \mathrm{~N}_{2} \mathrm{O}(\%)$ : C, 63.98; H, 6.71; N, 18.65; Found: C, 63.91; $\mathrm{H}, 6.74 ; \mathrm{N}, 18.62$.
$\mathbf{H}_{2} \mathbf{L}^{4}$ : A solution of 3-aminoacetophenone oxime (480.4 $\mathrm{mg}, 10 \mathrm{mmol})$ in ethanol $(10 \mathrm{~mL})$ was added dropwise to a solution of 2,2'-(ethylenedioxy)bisbenzaldehyde (270.4 mg, $1 \mathrm{mmol})$ in ethanol $(10 \mathrm{~mL})$ at room temperature. After the solution had been stirred and condensing refluxed at $55^{\circ} \mathrm{C}$ for $6 \mathrm{~h}$ and reduced to half by vacuum distillation, then put it in the refrigerator overnight, the formed precipitate was separated by filtration and washed successively with ethanol/hexane (1:4) and hexane, respectively. The product was dried under reduced pressure for $72 \mathrm{~h}$ to obtain pale pink powder $\mathrm{H}_{2} \mathrm{~L}^{4}$, Yield, $86.9 \%$. m.p. 472-473 K.

\section{RESULTS AND DISCUSSION}

A series of bisoximes-type compounds $\mathrm{H}_{2} \mathrm{~L}^{1}, \mathrm{~L}^{2}, \mathrm{~L}^{3}$ and $\mathrm{H}_{2} \mathrm{~L}^{4}$ have been synthesized with good yields and the compositions are confirmed by elemental analyses, IR and UV-visible spectra.

Physical and chemical properties of bisoximes compounds $\mathbf{H}_{2} \mathbf{L}^{1}, \mathbf{L}^{2}, \mathbf{L}^{3}$ and $\mathbf{H}_{2} \mathbf{L}^{4}$ : The colour, yields and elemental analytical results of the synthesized bisoximes compounds $\mathrm{H}_{2} \mathrm{~L}^{1}, \mathrm{~L}^{2}, \mathrm{~L}^{3}$ and $\mathrm{H}_{2} \mathrm{~L}^{4}$ are presented in Table- 1 .

Bisoximes-type compounds $\mathrm{H}_{2} \mathrm{~L}^{1}, \mathrm{~L}^{2}, \mathrm{~L}^{3}$ are white solid, $\mathrm{H}_{2} \mathrm{~L}^{4}$ is a pale pink solid and all the compounds stable in air and compounds $\mathrm{H}_{2} \mathrm{~L}^{1}, \mathrm{~L}^{2}, \mathrm{~L}^{3}$ soluble in ethanol, dichloromethane, THF and DMF, slightly soluble in acetone and methanol, insoluble in acetonitrile and $n$-hexane. Bisoximes-type compound $\mathrm{H}_{2} \mathrm{~L}^{4}$ soluble in acetone, ethanol and DMF, slightly soluble in acetone, THF and methanol and insoluble in acetonitrile and $n$-hexane.

IR spectra: The most important IR spectral data for the bisoximes compounds $\mathrm{H}_{2} \mathrm{~L}^{1}, \mathrm{~L}^{2}, \mathrm{~L}^{3}$ and $\mathrm{H}_{2} \mathrm{~L}^{4}$ are given in Table-2.

In the IR spectra of the the bisoximes compounds $\mathrm{H}_{2} \mathrm{~L}^{1}$, $\mathrm{L}^{2}, \mathrm{~L}^{3}$ and $\mathrm{H}_{2} \mathrm{~L}^{4}$, the bands due to characteristic $\mathrm{C}=\mathrm{N}$ stretching absorption bands appear at $1613-1607 \mathrm{~cm}^{-1}$, respectively ${ }^{8,10}$. The Ar-O stretching frequencies appear within 1264-1243 $\mathrm{cm}^{-1}$ as reported for similar bisoxime compounds ${ }^{8}$. These provide evidence for the formation of the title compounds. The $\mathrm{O}-\mathrm{H}$ stretching frequency of the bisoxime compound is expected in the $3300-3800 \mathrm{~cm}^{-1}$ region ${ }^{8}$, here a strong band at $3684-$ $3656 \mathrm{~cm}^{-1}$ was observed in the title compounds $\mathrm{H}_{2} \mathrm{~L}^{1}$ and $\mathrm{H}_{2} \mathrm{~L}^{4}$

\begin{tabular}{|c|c|c|c|c|c|c|c|}
\hline \multirow{3}{*}{ Compound } & \multicolumn{7}{|c|}{$\begin{array}{l}\text { TABLE-1 } \\
\text { COLOUR, YIELDS, MELTING POINTS AND ANALYTICAL DATA } \\
\text { FOR THE BISOXIMES-TYPE COMPOUNDS } \mathrm{H}_{2} \mathrm{~L}^{1}, \mathrm{~L}^{2}, \mathrm{~L}^{3} \text { AND } \mathrm{H}_{2} \mathrm{~L}^{4}\end{array}$} \\
\hline & \multirow{2}{*}{ Colour } & \multirow{2}{*}{ m.p. $(\mathrm{K})$} & \multirow{2}{*}{ Yield $(\%)$} & \multirow{2}{*}{ m.f. (m.w.) } & \multicolumn{3}{|c|}{ Elemental analysis (\%): Found (Calcd.) } \\
\hline & & & & & $\mathrm{C}$ & $\mathrm{H}$ & $\mathrm{N}$ \\
\hline $\mathrm{H}_{2} \mathrm{~L}^{1}$ & White & $354-355$ & 82.5 & $\mathrm{C}_{16} \mathrm{H}_{16} \mathrm{~N}_{2} \mathrm{O}_{4}(300.30)$ & $63.92(63.99)$ & $5.33(5.37)$ & $9.36(9.33)$ \\
\hline $\mathrm{L}^{2}$ & White & $445-445.5$ & 79.1 & $\mathrm{C}_{18} \mathrm{H}_{20} \mathrm{~N}_{2} \mathrm{O}_{4}(328.36)$ & $65.81(65.84)$ & $6.17(6.14)$ & $8.59(8.53)$ \\
\hline $\mathrm{L}^{3}$ & White & $337-338$ & 68.1 & $\mathrm{C}_{20} \mathrm{H}_{24} \mathrm{~N}_{2} \mathrm{O}_{4}(356.42)$ & $67.57(67.40)$ & $6.61(6.79)$ & $7.72(7.86)$ \\
\hline $\mathrm{H}_{2} \mathrm{~L}^{4}$ & Pale pink & $472-473$ & 86.9 & $\mathrm{C}_{32} \mathrm{H}_{30} \mathrm{~N}_{4} \mathrm{O}_{4}(534.61)$ & $71.91(71.89)$ & $5.63(5.66)$ & $10.45(10.48)$ \\
\hline
\end{tabular}

\begin{tabular}{ccccccc}
\multicolumn{7}{c}{ TABLE-2 } \\
KEY IR BANDS $\left(\mathrm{cm}^{-1}\right)$ FOR THE BISOXIMES-TYPE COMPOUNDS H $\mathrm{L}^{1}, \mathrm{~L}^{2}, \mathrm{~L}^{3} \mathrm{AND} \mathrm{H}_{2} \mathrm{~L}^{4}$ \\
\hline Compound & $v(\mathrm{C}=\mathrm{N})$ & $v(\mathrm{Ar}-\mathrm{O})$ & $v(\mathrm{O}-\mathrm{H})$ & $v(\mathrm{C}=\mathrm{C})_{\text {benzene ring }}$ & $v\left(\mathrm{CH}_{\text {arom }}\right)$ & $v\left(\mathrm{CH}_{2}\right)$ \\
\hline $\mathrm{H}_{2} \mathrm{~L}^{1}$ & 1609 & 1255 & 3656 & $1596,1545,1462$ & 3072 & 2930,2857 \\
$\mathrm{~L}^{2}$ & 1612 & 1246 & - & $1590,1553,1438$ & 3074 & 2933,2858 \\
$\mathrm{~L}^{3}$ & 1613 & 1243 & - & $1592,1548,1442$ & 3070 & 2936,2851 \\
$\mathrm{H}_{2} \mathrm{~L}^{4}$ & 1607 & 1264 & 3684 & $1596,1550,1445$ & 3075 & 2937,2848 \\
\hline
\end{tabular}


TABLE-3

UV-VISIBLE SPECTRAL DATA FOR THE BISOXIMES-TYPE COMPOUNDS $\mathrm{H}_{2} \mathrm{~L}^{1}, \mathrm{~L}^{2}, \mathrm{~L}^{3}$ AND $\mathrm{H}_{2} \mathrm{~L}^{4}$

\begin{tabular}{cccc}
\hline \multirow{2}{*}{ Compound } & $\mathrm{C}\left(\times 10^{-5} \mathrm{~mol} \mathrm{~L}^{-1}\right)$ & First band & Second band \\
\cline { 3 - 4 } & & $\lambda_{\max 1}(\mathrm{~nm})$ & $\lambda_{\max 2}(\mathrm{~nm})$ \\
\hline $\mathrm{H}_{2} \mathrm{~L}^{1}$ & 5.00 & 272 & 327 \\
$\mathrm{~L}^{2}$ & 5.00 & 270 & 325 \\
$\mathrm{~L}^{3}$ & 5.00 & 271 & 328 \\
$\mathrm{H}_{2} \mathrm{~L}^{4}$ & 5.00 & 275 & 316 \\
\hline
\end{tabular}

\begin{tabular}{|c|c|c|}
\hline \multicolumn{3}{|r|}{$\begin{array}{c}\text { TABLE-4 } \\
{ }^{1} \mathrm{H} \text { NMR DATA FOR THE BISOXIMES-TYPE COMPOUNDS } \mathrm{H}_{2} \mathrm{~L}^{1}, \mathrm{~L}^{2}, \mathrm{~L}^{3} \text { and } \mathrm{H}_{2} \mathrm{~L}^{4}\end{array}$} \\
\hline Compound & & ${ }^{1} \mathrm{H}$ NMR (400 MHz, $\left.\mathrm{CDCl}_{3}, \delta / \mathrm{ppm}\right)$ \\
\hline $\mathrm{H}_{2} \mathrm{~L}^{1}$ & $\begin{array}{c}\mathrm{C}_{16} \mathrm{H}_{16} \mathrm{~N}_{2} \mathrm{O}_{4} \\
(300.30) \\
\end{array}$ & $\begin{array}{l}4.51\left(\mathrm{~s}, 4 \mathrm{H}, \mathrm{CH}_{2} \mathrm{O}\right), 6.97(\mathrm{t}, 2 \mathrm{H}, J=7.8 \mathrm{~Hz}, \mathrm{ArH}), 7.16(\mathrm{~d}, J=7.6 \mathrm{~Hz}, 2 \mathrm{H}, \mathrm{ArH}), 7.35(\mathrm{t}, J=7.5 \mathrm{~Hz}, 2 \mathrm{H}, \mathrm{ArH}), \\
7.74(\mathrm{~d}, J=7.5 \mathrm{~Hz}, 2 \mathrm{H}, \mathrm{ArH}), 8.42(\mathrm{~s}, 2 \mathrm{H}, \mathrm{CH}=\mathrm{N}), 10.23(\mathrm{~s}, 2 \mathrm{H}, \mathrm{OH})\end{array}$ \\
\hline $\mathrm{L}^{2}$ & $\begin{array}{c}\mathrm{C}_{18} \mathrm{H}_{20} \mathrm{~N}_{2} \mathrm{O}_{4} \\
(328.36)\end{array}$ & $\begin{array}{l}4.06\left(\mathrm{~s}, 6 \mathrm{H}, \mathrm{CH}_{3} \mathrm{O}\right), 4.50\left(\mathrm{~s}, 4 \mathrm{H}, \mathrm{CH}_{2} \mathrm{O}\right), 6.96(\mathrm{t}, 2 \mathrm{H}, J=7.7 \mathrm{~Hz}, \mathrm{ArH}), 7.15(\mathrm{~d}, J=7.7 \mathrm{~Hz}, 2 \mathrm{H}, \mathrm{ArH}), 7.36(\mathrm{t}, J= \\
7.7 \mathrm{~Hz}, 2 \mathrm{H}, \mathrm{ArH}), 7.76(\mathrm{~d}, J=7.7 \mathrm{~Hz}, 2 \mathrm{H}, \mathrm{ArH}), 8.36(\mathrm{~s}, 2 \mathrm{H}, \mathrm{CH}=\mathrm{N})\end{array}$ \\
\hline $\mathrm{L}^{3}$ & $\begin{array}{c}\mathrm{C}_{20} \mathrm{H}_{24} \mathrm{~N}_{2} \mathrm{O}_{4} \\
(356.42) \\
\end{array}$ & $\begin{array}{l}3.92\left(\mathrm{~s}, 6 \mathrm{H}, \mathrm{CH}_{3}\right), 4.17\left(\mathrm{~m}, J=7.2 \mathrm{~Hz}, 4 \mathrm{H}, \mathrm{CH}_{2}-\mathrm{O}\right), 4.52\left(\mathrm{~s}, 4 \mathrm{H}, \mathrm{CH}_{2} \mathrm{O}\right), 6.95(\mathrm{t}, 2 \mathrm{H}, J=7.6 \mathrm{~Hz}, \mathrm{ArH}), 7.12(\mathrm{~d}, J \\
=7.9 \mathrm{~Hz}, 2 \mathrm{H}, \mathrm{ArH}), 7.39(\mathrm{t}, J=7.2 \mathrm{~Hz}, 2 \mathrm{H}, \mathrm{ArH}), 7.78(\mathrm{~d}, J=7.0 \mathrm{~Hz}, 2 \mathrm{H}, \mathrm{ArH}), 8.35(\mathrm{~s}, 2 \mathrm{H}, \mathrm{CH}=\mathrm{N})\end{array}$ \\
\hline $\mathrm{H}_{2} \mathrm{~L}^{4}$ & $\begin{array}{l}\mathrm{C}_{32} \mathrm{H}_{30} \mathrm{~N}_{4} \mathrm{O}_{4} \\
(534.61)\end{array}$ & $\begin{array}{l}3.97\left(\mathrm{~s}, 6 \mathrm{H}, \mathrm{CH}_{3}\right), 4.55\left(\mathrm{~s}, 4 \mathrm{H}, \mathrm{CH}_{2} \mathrm{O}\right), 6.86(\mathrm{~d}, J=7.2 \mathrm{~Hz}, 2 \mathrm{H}, \mathrm{ArH}), 6.95(\mathrm{t}, 4 \mathrm{H}, J=7.5 \mathrm{~Hz}, \mathrm{ArH}), 7.14(\mathrm{~d}, J= \\
7.0 \mathrm{~Hz}, 4 \mathrm{H}, \mathrm{ArH}), 7.32(\mathrm{t}, J=7.2 \mathrm{~Hz}, 4 \mathrm{H}, \mathrm{ArH}), 7.66(\mathrm{~d}, J=7.2 \mathrm{~Hz}, 2 \mathrm{H}, \mathrm{ArH}), 8.42(\mathrm{~s}, 2 \mathrm{H}, \mathrm{CH}=\mathrm{N}), 10.38(\mathrm{~s}, 2 \mathrm{H}, \\
\mathrm{OH})\end{array}$ \\
\hline
\end{tabular}

and assigned to phenolic alcohol stretching absorption bands. In addition, in the $1596-1442 \mathrm{~cm}^{-1}$ region, the observed bands were attributed to aromatic $\mathrm{C}=\mathrm{C}$ vibrations.

UV-visible and ${ }^{1} \mathbf{H}$ NMR Spectra: The absorption spectra of the bisoximes compounds $\mathrm{H}_{2} \mathrm{~L}^{1}, \mathrm{~L}^{2}, \mathrm{~L}^{3}$ and $\mathrm{H}_{2} \mathrm{~L}^{4}$ (Table-3), in diluted dichloromethane solution show that the spectra of $\mathrm{H}_{2} \mathrm{~L}^{1}, \mathrm{~L}^{2}, \mathrm{~L}^{3}$ and $\mathrm{H}_{2} \mathrm{~L}^{4}$.

The UV-visible spectra of the bisoximes compounds $\mathrm{H}_{2} \mathrm{~L}^{1}$, $\mathrm{L}^{2}, \mathrm{~L}^{3}$ and $\mathrm{H}_{2} \mathrm{~L}^{4}$ in $5 \times 10^{-5}$ DMF solution are presented in Table-3. The bisoximes compounds $\mathrm{H}_{2} \mathrm{~L}^{1}, \mathrm{~L}^{2}, \mathrm{~L}^{3}$ and $\mathrm{H}_{2} \mathrm{~L}^{4}$ exhibit two intense peaks at around 272 and $327 \mathrm{~nm}$. The former absorption peak at about $272 \mathrm{~nm}$ can be assigned to the $\pi-\pi^{*}$ transition of the benzene rings, while the latter can be attributed to the intra-ligand $\pi-\pi^{*}$ transition of the $\mathrm{C}=\mathrm{N}$ bonds ${ }^{11,12}$. It is of note that there was no absorption around $400 \mathrm{~nm}$, which is seen in the corresponding Salen derivatives. The absorption is ascribed to the quinoid form of $\mathrm{H}_{2}$ Salen $^{13}$.

The ${ }^{1} \mathrm{H}$ NMR spectra showed a singlet at about 8.35-8.42 ppm indicating the existence of oxime bonds ${ }^{13}$ (Table-4).

\section{Conclusion}

In this paper, a series of bisoximes-type compounds $\mathrm{H}_{2} \mathrm{~L}^{1}$, $\mathrm{L}^{2}, \mathrm{~L}^{3}$ and $\mathrm{H}_{2} \mathrm{~L}^{4}$ have been designed and synthesized by the reaction of 1 equivalents of 2,2'-(ethylenedioxy)bisbenzaldehyde with hydroxylamine hydrochloride, methoxyamine hydrochloride, ethyoxylamine hydrochloride or 3-aminoacetophenone oxime under hot ethanol conditions, respectively. It is shown that an O-alkyl oxime moiety is much more useful to assemble supramolecular systems. Further investigation on the synthesis and structures of bisoximes-type complexes with transition metal ions, are now in progress.

\section{ACKNOWLEDGEMENTS}

The authors thank The Young Scholars Science Foundation of Lanzhou Jiaotong University for financial support of this work.

\section{REFERENCES}

1. C. Meermann, K.W. Törnroos and R. Anwander, Inorg. Chem., 48, 2561 (2009).

2. L. Salmon, P. Thuéry and M. Ephritikhine, Polyhedron, 26, 631 (2007).

3. Z. Lu, M. Yuan, F. Pan, S. Gao, D. Zhang and D. Zhu, Inorg. Chem., 45, 3538 (2006).

4. K. Selmeczi, M. Réglier, M. Giorgi and G. Speier, Coord. Chem. Rev., 245, 191 (2003).

5. J. Tisato, F. Refosco and F. Bandoli, Coord. Chem. Rev., 135-136, 325 (1994).

6. N.S. Venkataramanan, G. Kuppuraj and S. Rajagopal, Coord. Chem. Rev., 249, 1249 (2005).

7. S.S. Sun, C.L. Stern, S.T. Nguyen and J.T. Hupp, J. Am. Chem. Soc., 126, 6314 (2004).

8. (a) W.K. Dong, Y.X. Sun, X.Y. Dong, S.J. Xing and L. Wang, J. Coord. Chem., 66, 3291 (2013); (b) W.K. Dong, L.S. Zhang, Y.X. Sun, M.M. Zhao, G. Li and X.Y. Dong, Spectrochim. Acta A, 121, 324 (2014); (c) W.-L. Dong, J.-M. Yue, Y.-Z. Qiao, L.-S. Song, Y.-Y. Niu and S.W. Ng, Synth. React. Inorg. Met.-Org. Nano-Met. Chem., 41, 598 (2011); (d) W.K. Dong, Y.X. Sun, C.Y. Zhao, X.Y. Dong and L. Xu, Polyhedron, 29, 2087 (2010).

9. I.M. Atkinson, L.F. Lindoy, O.A. Matthews, G.V. Meehan, A.N. Sobolev and A.H. White, Aust. J. Chem., 47, 1155 (1994).

10. S. Akine, T. Taniguchi, W. Dong, S. Masubuchi and T. Nabeshima, J. Org. Chem., 70, 1704 (2005).

11. I.M. Atkinson, L.F. Lindoy, O.A. Matthews, G.V. Meehan, A.N. Sobolev and A.H. White, Aust. J. Chem., 47, 1155 (1994).

12. T. Ghosh, B. Mondal, T. Ghosh, M. Sutradhar, G. Mukherjee and M. Drew, Inorg. Chim. Acta, 360, 1753 (2007).

13. H.E. Smith, Chem. Rev., 83, 359 (1983). 